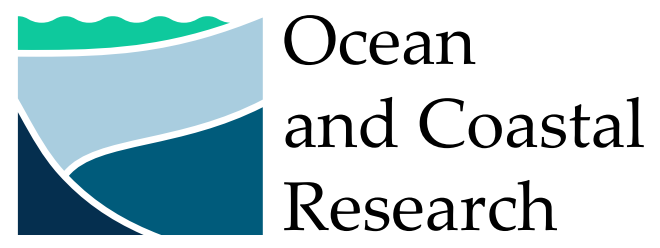

\title{
First record of the non-native medusa Blackfordia virginica (Hydrozoa, Leptomedusae) on the coast of Uruguay, Southwestern Atlantic
}

\author{
Victoria Mariel Vidal Madalena ${ }^{1, *(1)}$, María Sofía Dutto ${ }^{2}$, Irene Machado Baranzano ${ }^{10}$ \\ 1 Universidad de la Republica - Ecologia Funcional de Sistemas Acuaticos - CURE- Rocha (Ruta Nacional, 9 - Rocha - CP 27000 - Uruguay) \\ ${ }^{2}$ Instituto Argentino de Oceanografia - IADO-CONICET/UNS - (Camino La Carrindanga km 7.5 - Bahia Blanca - CP 8000 - Argentina) \\ *Corresponding author: victoria.vidal@cure.edu.uy
}

Marine invasions are a growing threat challenging the preservation of ocean biodiversity. These invasions occur in a context of global change due to increasing anthropogenic activities, with maritime transport being the main mechanism of introduction of aquatic invertebrates (Grigorovich et al., 2003). Shipping serves as a vector for the dispersal of organisms through ballast water, sediment, or hull fouling (Minchin \& Gollash, 2002). Aquaculture and aquarium trade are also vectors of transfer and introduction of alien species (Minchin, 2007; Grosholz et al., 2015).

Among marine species, hydrozoans are considered successful invaders due to their environmental flexibility, small size, wide variety of life cycles, and reproductive processes that allow them to be easily transported and to establish in new regions (Graham \& Bayha, 2008; Rilov and Crooks, 2009; Folino-Rorem et al., 2008). However, due to their relatively inconspicuous and seemingly low environmental impact on ecosystems, hydrozoans may be overlooked in invasion biology (Miglietta and Lessios, 2008). Nevertheless, there are several examples of invasions by hydromedusa species in different ecosystems around the world, including the cases of Maeotias marginata, Moerisia lyonsi, Gonionemus vertens, and Blackfordia virginica, among others (Ma \& Purcell, 2005, Gaynor et al., 2016, Harrison et al., 2013).

Submitted: 02-Oct-2020

Approved: 11-Sept-2021

Editor: Rubens M. Lopes

(C) 2021 The authors. This is an open access article distributed under the terms of the Creative Commons license.
Blackfordia virginica (Hydrozoa, Leptomedusae) is thought to be native to the Black and Caspian Sea and is recognized to be a successful invader of estuarine coastal waters around the world (Europe, North America, Asia, and Central America) (Bayha \& Graham, 2014). In the Southwestern Atlantic, it was recorded for the first time in the northeast of Brazil (Paranaguá, 1963) and then, nearly four decades later, in the Rio de la Plata estuary on the Argentine shelf (Genzano et al., 2006) and in different estuarine ecosystems along the southern and southeastern Brazilian coast (Nogueira \& Oliveira, 2006). This hydromedusa is considered an euryhaline species, which has been shown to tolerate a wide range of salinity, from 2.2 to 36 (Moore, 1987). It displays a metagenetic life cycle comprised of a benthic polyp phase, which reproduces asexually, and a planktonic sexual phase, the medusa. Pelagic medusae and benthic polyps have been observed in brackish water ecosystems, and polyps have also been found in estuaries and coastal saltwater swamps (Bardi \& Marques 2009). In several tropical and temperate estuaries, $B$. virginica occurs seasonally, developing higher biomasses and abundances at temperatures $\geq 14^{\circ} \mathrm{C}$ (e.g. Wintzer et al., 2013; Freire et al., 2013; Jaspers et al., 2018). It feeds on adults and nauplii of copepods, barnacle nauplii (Mills \& Sommer, 1995), and fish larvae (Wintzer et al., 2013). Morais et al. (2015) demonstrated that it also feed on phytoplankton and ciliates and is able to maintain a good nutritional condition during periods of low availability of metazooplanktonic prey, basing its diet on sources of particulate organic matter. 
Regarding the potential ecological impacts of the introduction of this hydromedusa in different ecosystems, some negative effects have been observed. In the Guadiana and Mira estuaries (Portugal) the occurrence of $B$. virginica was associated with the decrease in density of other zooplankton fractions, including fish eggs (Chícharo et al., 2009) and copepods (Marques et al., 2017). In the Napa and Petaluma Rivers, California (USA), $B$. virginica was capable of larval fish predation (Wintzer et al., 2013). The consumption of a wide range of prey, combined with its metagenetic life cycle and high tolerance to fluctuating environmental conditions, may explain why this species has successfully expanded its distribution and invaded different environments around the world.

Due to the potential negative effect invasions may cause to ecosystems, worldwide efforts are being directed to develop strategies and programs of biodiversity conservation (e.g. European Commission, 2008; Katsanevakis et al., 2016; Bourne et al., 2018). In Uruguay, inter-institutional groups are studying biological invasions to systematize information about bio-invaders (Brugnoli et al., 2009; Brugnoli \& Laufer, 2018). Nevertheless, studies on jellyfish are very scarce and correspond mainly to qualitative works (Failla, 2006; 2014; Leoni et al., 2016; Stampar et al., 2016). Here, we present the first record of the non-native hydromedusa $B$. virginica on the Uruguayan coast. The temporal dynamic of its abundance and its relationship with environmental conditions (temperature, salinity, and chlorophylla) during an annual cycle (February 2016- February 2017) were evaluated.

The study area was Laguna de Rocha (hereafter referred to as "the Lagoon") and its adjacent coastal waters $\left(34^{\circ} 35^{\prime} \mathrm{S}-54^{\circ} 17^{\prime} \mathrm{W}\right)$. This area is part of a system of coastal lagoons which extends from the eastern region of the Uruguayan coast to southern Brazil (Figure 1). The Lagoon (mean depth $=0.6 \mathrm{~m}$; area $=72 \mathrm{~km}^{2}$ ) has an intermittent connection with the Atlantic Ocean through a naturally opening and closing sand bar; it alternates between closed and open states. Natural openings result either from high lagoon water levels or strong wave action. During the closed state, typically stable physicochemical characteristics of the water are found along the lagoon. However, these conditions, as well as the biological communities, may suffer drastic spatio-temporal variability during the open sandbar state due to the mixing of fresh water with marine intrusions (Conde et al., 2019). Because of its natural and cultural values, the Lagoon has been internationally recognized as a Ramsar site and a MaB Biosphere Reserve and was included in the National System of Protected Areas of Uruguay (Rodriguez-Gallego et al., 2013).

Sampling was conducted during an annual cycle, mostly every 60 days between February 2016 and February 2017, covering both the open and closed states of the sandbar (Table 1). For the open sandbar state, sampling frequency was increased to every 7-15 days to evaluate the effect of the open regime on the gelatinous zooplankton community in the Lagoon. Four stations within the Lagoon (Stn 1, Stn 2, Stn 3, Stn 4) and two stations in the adjacent coastal waters (Stn 5, Stn 6) were sampled (Figure 1). A total of 15 samplings were carried out during the study period (S1 to S15). Three sampling campaigns in adjacent coastal waters had to be canceled due to adverse weather conditions for navigation (Table 1). Samples were collected with an epibenthic sled $(1 \mathrm{~m} \mathrm{x}$ $1 \mathrm{~m}$, mesh $500 \mu \mathrm{m}$ ) within the Lagoon and with a conic plankton net (mouth diameter: $0.6 \mathrm{~m}$, mesh: 500 $\mu \mathrm{m}$ ) in the adjacent coastal waters. Both nets were equipped with a flowmeter to estimate the volume of filtered water. The sled and plankton net were towed for 5 minutes at a speed of 2 knots. The average volume of filtered water was $42 \mathrm{~m}^{3}$ in the Lagoon and 38 $\mathrm{m}^{3}$ in adjacent coastal waters. Samples were fixed in formaldehyde $4 \%$. Samples were collected at a depth between 0.5 and $1.8 \mathrm{~m}$ inside the lagoon and at $3 \mathrm{~m}$ in the adjacent coastal waters. Water temperature $\left({ }^{\circ} \mathrm{C}\right)$ and salinity were measured once using a multiparameter probe (Horiba U-50) at the time of plankton sampling. Subsurface water samples were taken for the estimation of chlorophyll- $a\left(\mathrm{~g} \mathrm{I} \mathrm{I}^{-1}\right)$ (Parsons, 1984). In the laboratory, hydromedusa specimens were identified and quantified under a stereoscopic microscope. Numerical abundance was standardized to individuals per $\mathrm{m}^{3}$ (ind. $\mathrm{m}^{-3}$ ). To evaluate the relationship between the recorded environmental variables and the abundance of B. virginica, the Spearman test was performed using $\mathrm{R}$ software version 3.6.3 and RStudio (RStudio team., 2015).

Blackfordia virginica was recorded only within the lagoon and was absent in the adjacent coastal waters. 


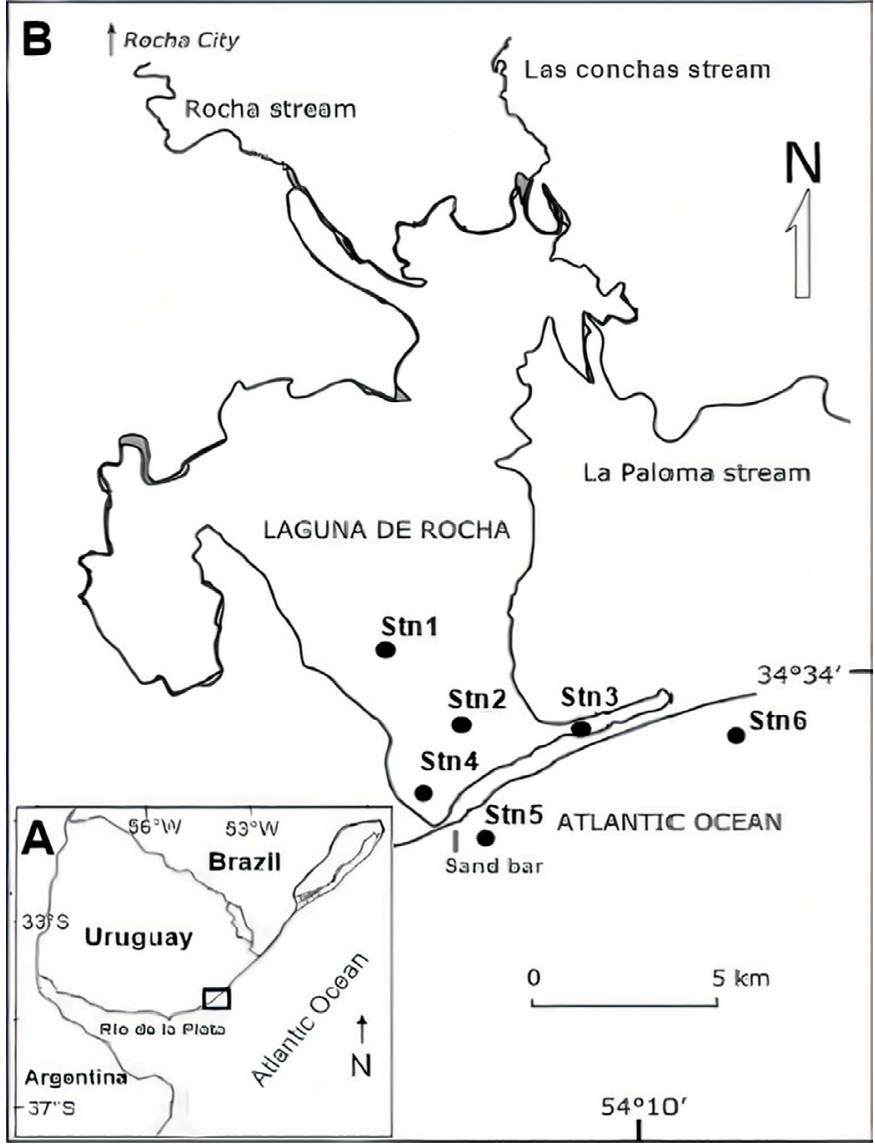

Figure 1. A) Location of Laguna de Rocha (black box) on the coast of Uruguay in the Southwestern Atlantic. B) The sampling stations inside Laguna de Rocha (Stn $1, \operatorname{Stn} 2, \operatorname{Stn} 3, \operatorname{Stn} 4)$ and in the adjacent coastal waters (Stn $5, \operatorname{Stn} 6)$ are indicated with black circles.

It was more abundant in February (1.1-15.9 ind. $\mathrm{m}^{-3}$ in 2016 and $0.50-17.3 \mathrm{~m}^{-3}$ in 2017) during the closed sandbar state (Figure 2). Regarding the spatial variability in the abundance of $B$. virginica, the highest value was 17.3 ind. $\mathrm{m}^{-3}$, recorded in Stn 4 in February 2017, and 15.9 ind. $\mathrm{m}^{-3}$ in Stn 2 in February 2016. During spring, the abundance was low $\left(0.1\right.$ ind. $\left.\mathrm{m}^{-3}\right)$, and the hydromedusa was not recorded in winter (Figure 2). Blackfordia virginica was collected in wide ranges of temperature $\left(14.1\right.$ to $\left.28.6^{\circ} \mathrm{C}\right)$, salinity $(10.0$ to 26.7), and chlorophyll-a (1.4 to $6.9 \mu^{-1}$ ) (Figure 2), and its abundance was significantly correlated with temperature ( $r s=0.6 ; p=0.01 ; \mathrm{N}=15$ ).

Here we present the first record of the invasive jellyfish $B$. virginica on the Uruguayan coast. The environmental conditions of the Lagoon (i.e., brackish and shallow environment) seem to favour the growth of $B$. virginica populations, mainly during warm periods and the closed sandbar state, perhaps due to the stable physicochemical conditions in the water column and high chlorophyll- $a$. However, further research is needed to evaluate the effect of the sandbar state on the abundance of this hydromedusa. The occurrence of maximum abundances during warmer periods of the year agrees with records in other subtropical and temperate estuarine and brackish water ecosystems, both at a regional and on a global scale (Río de la Plata: Genzano et al. 2006; southeastern and southern Brazil: Nogueira \& de Oliveira, 2006; Bardi \& Marques, 2009; west coast of USA, California: Wintzer et al., 2013; southern and northern Europe: Nowaczyk et al., 2016; Marques et al., 2017; Jaspers et al., 2018). Besides temperature, another environmental factor which seems to be associated with the occurrence of $B$. virginica is salinity. Blackfordia virginica is characterized by a high salinity tolerance and a 
Table 1. Sampling performed from February 2016 to February 2017 (S1 to S15) at Laguna de Rocha and its adjacent coastal waters on the Uruguayan coast. Dates, sandbar state (open/closed) and environmental variables measured in each sampling stations are shown. The hyphen indicates missing sampling campaings due to adverse weather conditions for navigation. Stn: sampling station. Stn 1: $34^{\circ} 38^{\prime} 5.60^{\prime \prime} \mathrm{S}, 54^{\circ} 17^{\prime} 10.35^{\prime \prime} \mathrm{W}$; St 2: $34^{\circ} 39^{\prime} 23.80^{\prime \prime} \mathrm{S} 54^{\circ} 16^{\prime} 19.56^{\prime \prime} \mathrm{W}$, Stn 3:

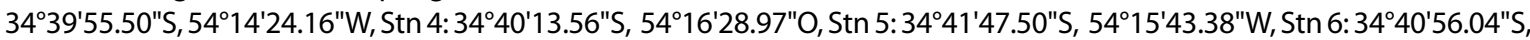
$54^{\circ} 12^{\prime} 2.66^{\prime \prime} \mathrm{O}$. Chlo: Chlorophyll-a, S: salinity, T: temperature.

\begin{tabular}{|c|c|c|c|c|c|}
\hline Samplings & Laguna de Rocha & Coastal waters & Stations & Variables & Sand bar state \\
\hline S1 & $16 / 02 / 16$ & $26 / 02 / 2016$ & Stn $1,2,5,6$ & Chlo, S, T, abundance & Closed \\
\hline S2 & $30 / 03 / 2016$ & $31 / 03 / 2016$ & Stn $1,2,5,6$ & Chlo, S, T, abundance & Closed \\
\hline S3 & $21 / 04 / 2016$ & $22 / 04 / 2016$ & Stn $1,2,5,6$ & Chlo, S, T, abundance & Open \\
\hline S4 & $30 / 04 / 2016$ & 05/05/2016 & Stn $1,2,3,4,5,6$ & Chlo, S, T, abundance & Open \\
\hline S5 & $13 / 06 / 2016$ & $15 / 06 / 2016$ & Stn $1,2,3,4,5,6$ & Chlo, S, T, abundance & Open \\
\hline S6 & $28 / 07 / 2016$ & 09/08/2016 & Stn $1,2,3,4,5,6$ & Chlo, S, T, abundance & Open \\
\hline S7 & $06 / 10 / 2016$ & $07 / 10 / 2016$ & Stn $1,2,3,4,5,6$ & Chlo, S, T, abundance & Open \\
\hline S8 & $14 / 10 / 2016$ & - & Stn $1,2,3,4$ & Chlo, S, T, abundance & Open \\
\hline S9 & $21 / 10 / 2016$ & $22 / 10 / 2016$ & Stn $1,2,3,4,5,6$ & Chlo, S, T, abundance & Closed \\
\hline S10 & 29/10/2016 & - & Stn $1,2,3,4$ & Chlo, S, T, abundance & Open \\
\hline S11 & $04 / 11 / 2016$ & - & Stn $1,2,3,4$ & Chlo, S, T, abundance & Open \\
\hline S12 & $14 / 11 / 2016$ & $15 / 11 / 2016$ & Stn $1,2,3,4,5,6$ & Chlo, S, T, abundance & Open \\
\hline S13 & 29/11/2016 & $30 / 11 / 2016$ & Stn $1,2,3,4,5,6$ & Chlo, S, T, abundance & Open \\
\hline S14 & $15 / 12 / 2016$ & $21 / 12 / 2016$ & Stn $1,2,3,4,5,6$ & Chlo, S, T, abundance & Open \\
\hline S15 & $14 / 02 / 2017$ & $03 / 02 / 2017$ & Stn $1,2,3,4,5,6$ & Chlo, S, T, abundance & Closed \\
\hline
\end{tabular}

brackish-water habitat preference (Moore 1987; Bardi $\&$ Marques, 2009). Shallow coastal environments also seem to be apt for the development of this species (Bayha \& Graham, 2014). Therefore, the environmental context of the Lagoon, characterized by salinity gradients and shallowness, matches the ecological preferences of $B$. virginica.

With respect to the abundance values found in different ecosystems, we did not find a clear pattern associated with a latitudinal range. However, the highest abundances were observed in certain northern subtropical and temperate habitats (Mira Estuary, Gironde Estuary and San Francisco Estuary, see Table 2). The abundances observed in this study were similar to those recorded by Genzano et al. (2006) in the Río de la Plata estuary (Argentina-Uruguay) and by Bardi \& Marques (2009) in shallow bays and channels from southeastern and southern Brazil. This may suggest that $B$. virginica consistently shows lower abundances in comparison to certain northern temperate estuaries and/or that this hydromedusa is at an early stage of its establishment in our study area.

The introduction of $B$. virginica in the Río del Plata estuary (Figure 1), one of the large waterways of South America, is probably related to the intense trans-oceanic shipping traffic in the region, as observed in other invaded estuarine and brackish water ecosystems worldwide (Genzano et al., 2006), such as the Kiel channel (Jaspers et al., 2018), San Francisco Estuary (Wintzer et al., 2011), Gironde Estuary (Nowaczyk et al., 2016), and Bombay Harbor (Santhakumaki, 1999). Laguna de Rocha is located relatively close $(\sim 300 \mathrm{~km})$ to international trade ports (e.g. Montevideo and Rio Grande). Also, shelf currents and the estuarine plume of Rio de la Plata, which reaches this part of the coast (Moreira \& Simionato 2019), may favour the arrival of invasive species found in nearby ecosystems. Blackfordia virginica has invaded tropical and subtropical estuaries in the SW Atlantic (Freire et al. 2014), and our observations suggest it has now been successfully introduced to the Río de la Plata region, following the first recorded instances in Argentinean waters in 2000 (Genzano et al., 2006) and 2006 (Dutto et al., 2019).

In the current scenario of global and regional warming (Johnson \& Lyman, 2020), the effects on water temperature may contribute to the distributional expansion of $B$. virginica populations, promoting settlement and growth in the invaded environments (Marques et al., 2017; Jaspers et al., 2018). The 

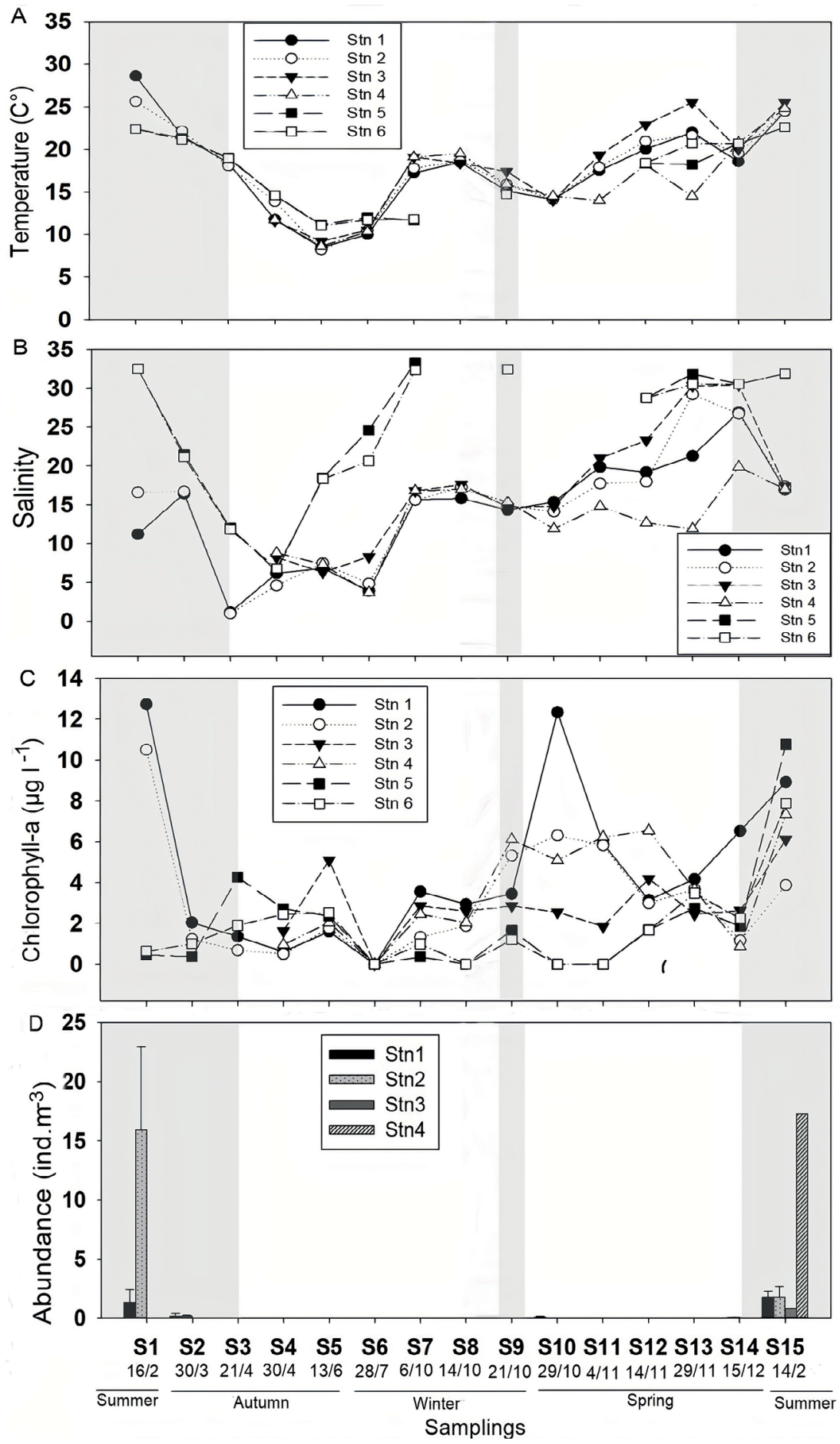

Figure 2. A) Temperature $\left.\left({ }^{\circ} \mathrm{C}\right), \mathrm{B}\right)$ Salinity, C) Chlorophyll- $a\left(\mu \mathrm{gl}^{-1}\right)$, and D) Blackfordia virginica abundance (ind. $m-3 \pm S D$ ) in Laguna de Rocha (Stn 1, Stn 2, Stn 3, Stn 4) and in the coastal waters (Stn 5, Stn 6) from February 2016 to February 2017. B. virginica was only recorded in Laguna de Rocha. Gray shadings indicate closed sandbar state. 
Table 2. Records of Blackfordia virginica with their respective abundance (ind. $\left.\mathrm{m}^{-3}\right)$, temperature $\left({ }^{\circ} \mathrm{C}\right)$, and salinity ranges if available. The location, latitude, and type of ecosystem of the records are also included.

\begin{tabular}{|c|c|c|c|c|c|}
\hline Region & Latitude & Abundance & Temperature & Salinity & Reference \\
\hline Kiel fjord (Germany) & $54^{\circ} 30^{\prime} \mathrm{N}$ & $0.7-14.4$ & $8.7-18.0$ & $7.0-13.0$ & Jaspers et al., 2018 \\
\hline $\begin{array}{l}\text { Gironde Estuary } \\
\text { (Atlantic,France) }\end{array}$ & $45^{\circ} 15^{\prime} \mathrm{N}$ & $0.5-637.0$ & $15.5-23.0$ & $6.8-22.9$ & Nowaczyk et al., 2016 \\
\hline San Francisco Bay (USA, Pacific) & $38^{\circ} 16^{\prime} \mathrm{N}$ & - & $17.0-21.0$ & $14.0-17.0$ & Mills \& Sommer, 1995 \\
\hline San Francisco Bay (USA, Pacific) & $38^{\circ} 16^{\prime} \mathrm{N}$ & - & 16 & 19 & Mills \& Rees, 2000 \\
\hline Napa and Petaluma Rivers (USA) & $38^{\circ} 06^{\prime} \mathrm{N}$ & $5.0-232.0$ & $20.0-23.1$ & $16.5-22.2$ & Wintzer et al., 2013 \\
\hline Mira estuary (Portugal) & $37^{\circ} 43^{\prime} \mathrm{N}$ & $66.6 *$ & - & 22,8 & Moore, 1987 \\
\hline $\begin{array}{l}\text { Guadiana Estuary (SE-Portugal/ } \\
\text { SW-Spain) }\end{array}$ & $37^{\circ} 09^{\prime} \mathrm{N}$ & $4.0-31.7$ & - & $8.0-29.0$ & Chicharo et al., 2009 \\
\hline Mira estuary (Portugal) & $37-35^{\circ} \mathrm{N}$ & $30.6-982.3$ & $23.6-26.1$ & $0.1-33,0$ & Marques et al., 2017 \\
\hline Lake Pontchartrain (USA) & $30^{\circ} 05^{\prime} \mathrm{N}$ & - & - & $5.0-23-0$ & Harrison et al., 2013 \\
\hline Bombay harbour (India) & $18^{\circ} 45^{\prime} \mathrm{N}$ & $4.0-72.0$ & - & - & $\begin{array}{l}\text { Santhakumari et al., } \\
1999\end{array}$ \\
\hline Pernanbuco bays (Brazil) & $8^{\circ} 03^{\prime} \mathrm{S}$ & - & $26.8-29.5$ & $2.2-36.0$ & Freire et al., 2013 \\
\hline Baía de Antonina (Brazil) & $25^{\circ} 32^{\prime} \mathrm{S}$ & $0.027-0.025$ & $26.0-27.0$ & $2.0-11.0$ & $\begin{array}{c}\text { Nogueira \& de Oliveira, } \\
2006\end{array}$ \\
\hline $\begin{array}{l}\text { Cananéia estuarine complex, } \\
\text { Paranaguá, Guaratuba and } \\
\text { Babitonga Bay (Brazil) }\end{array}$ & $25^{\circ}-26^{\circ} 05^{\prime} \mathrm{S}$ & $0.46-105.7$ & $21.5-30.5$ & $10.0-30.0$ & Bardi \& Marques, 2009 \\
\hline Río de la Plata (Argentina) & $36^{\circ} 05^{\prime} \mathrm{S}$ & $0.013-29.5$ & $23.5-24.3$ & $23.0-29.7$ & Genzano et al., 2006 \\
\hline This study & $34^{\circ} 41^{\prime} \mathrm{S}$ & $0.50-17.3$ & $14.1-28.6$ & $10.0-26.7$ & \\
\hline
\end{tabular}

- Abundance range was not available.

substantial environmental tolerance of the species and its metagenetic life cycle, which increase the probability of entering a given ecosystem, may facilitate the invasion of this jellyfish (Bayha \& Graham, 2014). Monitoring the species in the invaded habitats and comparing the abundances at various geographical points are imperative to understand the dynamics of the species invasion.

Recent coordinated work at a regional level has highlighted the need to develop databases for marine species introduction in the Southwestern Atlantic (Schwindt et al., 2020). This means that biological invasions derived from global anthropic activities must be considered an issue of regional importance with potential ecological and economic impacts. As such, early detection could be extremely important in protected areas like Laguna de Rocha. Further research, including a study of the $B$. virginica life cycle, is needed to properly understand the degree of establishment of this hydrozoan species and its potential impact on the Lagoon. Our study contributes valuable information to the knowledge base of an exotic invasive species in Uruguayan coastal waters as well as for the management of biodiversity in priority conservation areas. It also contributes to the knowledge of the geographical distribution of $B$. virginica and its ecological preferences.

\section{ACKNOWLEDGMENTS}

We thank all colleagues involved in the field surveys and laboratory analysis. Special thanks to D. Calliari, L. Rodríguez-Gallego, C. Lescano, C. Vidal, M. Cassou, S. Pasquariello and National System of Protected Areas (SNAP) and their rangers land A. Sosa and D. Sosa. This study was possible due to the funds provided by Comisión Sectorial de Investigación Científica (CSIC, Iniciación a la Investigación Program Grant ID70), PEDECIBA Doctoral Program, and CSIC doctoral fellowship. 


\section{AUTHOR CONTRIBUTIONS}

\author{
V.M.V.M., M.S.D., I.M.B.: Writing - original draft; Writing \\ - review \& editing.
}

\section{REFERENCES}

BARDI, J. \& MARQUES, A. C. 2009. The invasive hydromedusae Blackfordia virginica Mayer, 1910 (Cnidaria: Blackfordiidae) in southern Brazil, with comments on taxonomy and distribution of the genus Blackfordia. Zootaxa, 2198(1), 41-50.

BAYHA, K. M. \& GRAHAM, W. M. 2014. Nonindigenous marine jellyfish: invasiveness, invasibility, and impacts. In: PITT, K. A. \& LUCAS, C. H. (eds.). Jellyfish blooms. Dordrecht: Springer, pp. 45-77.

BRUGNOLI, E. \& LAUFER, G. 2018. Ecología, manejo y control de especies exóticas e invasoras en Uruguay, del diagnóstico a la acción. Montevideo: MVOTMA (Ministerio de Vivienda Ordenamiento Territorial y Medio Ambiente).

BRUGNOLI, E., MASCIADRI, S. \& MUNIZ, P. 2009. Base de datos de especies exóticas e invasoras en Uruguay, un instrumento para la gestión ambiental y costera. Montevideo: InBUy (Base de datos de Invasiones Biológicas para Uruguay).

BOURNE, S., HUDSON, J., HOLMAN, L. E. \& RIUS, M. 2018. Marine invasion genomics: revealing ecological and evolutionary consequences of biological invasions. London: Springer Nature.

CHÍCHARO, M., LEITÃO, T., RANGE, P., GUTIERREZ, C., MORALES, J., MORAIS, P. \& CHÍCHARO, L. 2009. Alien species in the Guadiana Estuary (SE-Portugal/SW-Spain): Blackfordia virginica (Cnidaria, Hydrozoa) and Palaemon macrodactylus (Crustacea, Decapoda): potential impacts and mitigation measures. Aquatic Invasions, 4(3), 501-506.

COMMISSION OF THE EUROPEAN COMMUNITIES, 2008. Towards an EU strategy on invasive species. Brussels: Commission of the European Communities.

CONDE, D., SOLARI, S., DE ÁLAVA, D., RODRÍGUEZ-GALLEGO, L., VERRASTRO, N., CHRETIES, C., LAGOS, X., PIÑEIRO, G., TEIXEIRA, L., SEIJO, L., VITANCURT, J., CAYMARIS, H. \& PANARIO, D. 2019. Ecological and social basis for the development of a sand barrier breaching model in Laguna de Rocha, Uruguay. Estuarine, Coastal and Shelf Science, 219, 300-316.

DUTTO, M., CHAZARRETA, C., RODRIGUEZ, C., SCHIARITI, A., DIAZ BRIZ, L. \& GENZANO, G. 2019. Macroscale abundance patterns of hydromedusae in the temperate Southwestern Atlantic $\left(27^{\circ}-56^{\circ} \mathrm{S}\right)$. PLoS One, 14(6), 217-228.

FOLINO-ROREM, N., DARLING, J. \& D'AUSILIO, C. 2008. Genetic analysis reveals multiple cryptic invasive species of the hydrozoan genus Cordylophora. Biological Invasions, 11(8), 1869-1882.

FREIRE, M., GENZANO, G., NEUMANN-LEITÃO, S. \& PÉREZ, C. D. 2013. The non-indigenous medusa Blackfordia virginica (Hydrozoa, Leptothecata) in tropical Brazil: 50 years of unnoticed presence. Biological Invasions, 16(1), 1-5.

GAYNOR, J. J., BOLOGNA, P. A. X., RESTAINO, D. \& BARRY, C. L. 2016. First occurrence of the invasive hydrozoan Gonionemus vertens A. Agassiz, 1862 (Cnidaria: Hydrozoa) in New Jersey, USA. Biolnvasions Records, 5(4), 233-237.

GENZANO, G., MIANZAN, H., ACHA, E. \& GAITÁN, E. 2006. First record of the invasive medusa Blackfordia virginica (Hydrozoa: Leptomedusae) in the Río de la Plata estuary, Argentina-Uruguay. Revista Chilena de Historia Natural, 79(2), 257-261.
GRAHAM, W. M. \& BAYHA, K. M. 2008. Biological invasions by marine jellyfish. In: NENTWIG, W. (ed.). Biological invasions. Berlin: Springer.

GRIGOROVICH, I., THERRIAULT, T. \& MACISAAC, H. J. 2003. History of aquatic invertebrate invasions in the Caspian Sea. In: PEDERSON, J. (ed.). Marine bioinvasions: patterns, processes and perspectives. Dordrecht: Springer, pp. 103-115.

GROSHOLZ, E. D., CRAFTON, R. E., FONTANA, R. E., PASARI, J. R., WILLIAMS, S. L. \& ZABIN, C. J. 2015. Aquaculture as a vector for marine invasions in California. Biological Invasions, 17(5), 1471-1484.

HARRISON, G. F., KIM, K. K. \& COLLINS, A. G. 2013. Low genetic diversity of the putatively introduced, brackish water hydrozoan, Blackfordia virginica (Leptothecata: Blackfordiidae), throughout the United States, with a new record for Lake Pontchartrain, Louisiana. Biological Society of Washington, 126(2), 91-102.

JASPERS, C., HUWER, B., WEILAND-BRÄUER, N. \& CLEMMESEN, C. 2018. First record of the non-indigenous jellyfish Blackfordia virginica (Mayer, 1910) in the Baltic Sea. Helgoland Marine Research, 72(1), 13.

JOHNSON, G. C. \& LYMAN, J. M. 2020. Warming trends increasingly dominate global ocean. Nature Climate Change, 10(8), 757-761.

KATSANEVAKIS, S. M., TEMPERA, C. F. \& TEIXEIRA, H. G. 2016. Mapping the impact of alien species on marine ecosystems: the Mediterranean Sea case study. Diversity and Distributions, 22(6), 694-707.

LEONI, V., GONZÁLEZ, S., ORTEGA, L., SCARABINO, F., FAILLA, G. F., DUTRA, A., RUBIO, L., ABREU, M., SERRA, W., CAMPI, A. G. C., STAMPAR, S. \& MORANDINI, A. 2016. Tamoya haplonema (Cnidaria: Cubozoa) from Uruguayan and adjacent waters: oceanographic context of new and historical findings. Marine Biodiversity Records, 9(1), 92.

MA, X. \& PURCELL, J. E. 2005. Temperature, salinity, and prey effects on polyp versus medusa bud production by the invasive hydrozoan Moerisia lyonsi. Marine Biology, 147(1), 225-234.

MARQUES, F., ANGÉLICO, M. M., COSTA, J. L., TEODÓSIO, M. A., PRESADO, P., FERNANDES, A., CHAINHO, P. \& DOMINGOS, I. 2017. Ecological aspects and potential impacts of the non-native hydromedusa Blackfordia virginica in a temperate estuary. Estuarine, Coastal and Shelf Science, 197, 69-79.

MIGLIETTA, M. P. \& LESSIOS, H. A. 2008. A silent invasion. Biological Invasions, 11(4), 825-834.

MILLS, C. E. \& REES, J. T. 2000. New observations and corrections concerning the trio of invasive hydromedusae Maeotias marginata ( $=\mathrm{M}$. inexpectata), Blackfordia virginica, and Moreisia sp. in the San Francisco Estuary. Scientia Marina, 64(Suppl 1), 151-155.

MILLS, C. E. \& SOMMER, F. 1995. Invertebrate introductions in marine habitats: two species of hydromedusae (Cnidaria) native to the Black Sea, Maeotias inexspectata and Blackfordia virginica, invade San Francisco Bay. Marine Biology, 122, 279-288.

MINCHIN, D. 2007. Aquaculture and transport in a changing environment: overlap and links in the spread of alien biota. Marine Pollution Bulletin, 55(7-9), 302-313.

MINCHIN, D. \& GOLLASCH, S. 2002. Vectors - how exotics get around. Invasive Aquatic Species of Europe. Distribution, Impacts and Management, 183-192. 
MOORE, S. J. 1987. Redescription of the leptomedusan Blackfordia virginica. Journal of the Marine Biological Association of the United Kingdom, 67(2), 287-291.

MORAIS, P., PARRA, M., MARQUES, R., CRUZ, J., ANGÉLICO, M. M., CHAINHO, P., COSTA, J., BARBOSA, A. \& TEODÓSIO, M. 2015. What are jellyfish really eating to support high ecophysiological condition? Journal of Plankton Research, 37(5), 10361041.

MOREIRA, D. \& SIMIONATO, C. 2019. Hidrología y circulación del estuario del Río de la plata. Meteorológica, 44(1), $1-30$.

NOGUEIRA JUNIOR., M. \& OLIVEIRA, J. S. 2006. Moerisia inkermanica (Hydrozoa; Moerisidae) e Blackfordia virginica (Hydrozoa; Blackfordiidae) na Baía de Antonina, Paraná, Brasil. Pan-American Journal of Aquatic Sciences, 1(1), 3542.

NOWACZYK, A., DAVID, V., LEPAGE, M., GOARANT, A., OLIVEIRA, E. \& SAUTOUR, B. 2016. Spatial and temporal patterns of occurrence of three alien hydromedusae, Blackfordia virginica (Mayer, 1910), Nemopsis bachei (Agassiz, 1849) and Maeotias marginata (Modeer, 1791), in the Gironde Estuary (France). Aquatic Invasions, 11(4), 397-409.

PARANAGUÁ, M. N. 1963. Sobre uma nova ocorrência de Blackfordia virginica (Mayer, 1910) e Ostrumovia inkermanica (Hadzi, 1928) (Hydromedusae). Trabalhos do Instituto Oceanográfico da Universidade do Recife, 5-6, 141-145.

PARSONS, T. R., MAITA, Y. \& LALLI, C. M. 1984. A manual of chemical \& biological methods for seawater analysis. New York: Pergamon Press.

RILOV, G. \& CROOKS, J. A. 2009. Biological invasions in marine ecosystems. Berlin: Springer-Verlag.
RODRÍGUEZ-GALLEGO, L., SANTOS, S., AMADO, S., GORFINKIEL, D., GONZÁLEZ, M. N., GÓMEZ, J., NEME, C., TOMMASINO, H. \& CON$\mathrm{DE}, \mathrm{D}$. 2013. Interdisciplinary diagnosis and scenario analysis for the implementation of a coastal protected area, Laguna de Rocha Uruguay. In:YÁÑEZ-ARANCIBIA, A., DÁVALOS-SOTELO, R. \& DAY, J. W. (eds.). Ecological dimensions for sustainable socio economic development. Boston: WIT Transactions on State of the Art in Science and Engineering, pp. 389-411.

RSTUDIO. 2020. Rstudio|Open source \& professional software for data science teams [online]. Boston: RSTUDIO. Available at: http:// www.rstudio.com/ [Accessed: 22 Mar. 2020].

SANTHAKUMARI, V., TIWARI, L. R. \& NAIR, V. R. 1999. Species composition, abundance and distribution of hydromedusae from Dharamtar estuarine system, adjoining Bombay harbour. National Institute of Science Communication (NISCOM), 28(2), 158-162.

SCHWINDT, E., CARLTON, J., ORENSANZ, J., SCARABINO, F. \& BORTOLUS, A. 2020. Past and future of the marine bioinvasions along the Southwestern Atlantic. Aquatic Invasions, 15(1), 11-29.

SIQUIER, M. G. F. 2006. Zooplancton gelatinoso de la costa uruguaya. In: MENAFRA, R., RODRIGUEZ-GALLEGO, L., SCARABINO, F. \& CONDE, D. (eds.). Bases para la conservación y el manejo de la costa Uruguaya. Montevideo: Vida Silvestre Uruguay, pp. 667.

STAMPAR, S. N., ROSA, F. C., ORTEGA, L., LEONI, V., SCARABINO, F., BENETI, J. S., ABREU, M. \& MORANDINI, A. C. 2016. First record along the Uruguayan coast of the largest sea nettle jellyfish, Chrysaora plocamia (Lesson, 1830) (Cnidaria: Scyphozoa). Check List, 12(4), 1934.

WINTZER, A. P., MEEK, M. H. \& MOYLE, P. B. 2013. Abundance, size, and diel feeding ecology of Blackfordia virginica (Mayer, 1910), a non-native hydrozoan in the lower Napa and Petaluma Rivers, California (USA). Aquatic Invasions, 8(2), 147-156. 